\title{
FSH-stimulated follicle development in ewes in high and low body condition and chronically treated with gonadotrophin-releasing hormone agonist
}

\author{
S. M. Rhind ${ }^{1}$, P. J. Goddard ${ }^{1}$, S. R. McMillen ${ }^{1}$ and A. S. McNeilly ${ }^{2}$ \\ ${ }^{1}$ The Macaulay Land Use Research Institute, Craigiebuckler, Aberdeen AB9 2QJ, UK; and \\ ${ }^{2}$ MRC Unit of Reproductive Biology, 37 Chalmers Street, Edinburgh EH3 9EW, UK
}

\begin{abstract}
Ovarian follicle development in response to FSH infusion was investigated in Scottish Blackface ewes with high and low body condition scores in which endogenous gonadotrophin secretion and follicle development to $\geqslant 2.5 \mathrm{~mm}$ diameter was suppressed using subcutaneous implants containing a GnRH agonist. In two experiments conducted during the normal breeding season, groups of 20 (Expt 1) and 15 (Expt 2) ewes were fed to achieve body condition scores $\geqslant 2.75$ (high; $\mathrm{H}$ ) or $\leqslant 1.75$ (low; L). In both experiments GnRH agonist implants were inserted four weeks before FSH was infused for $72 \mathrm{~h}$ at $7 \mu \mathrm{g} \mathrm{h}^{-1}$ to group $\mathrm{H}$ animals or at $5 \mu \mathrm{g} \mathrm{h}^{-1}$ to group $\mathrm{L}$ animals; the infusion rates were designed to ensure similar circulating FSH concentrations in animals of both groups. In Expt 2, additional subcutaneous implants containing oestradiol were inserted 21 days after insertion of GnRH agonist implants and 7 days before the FSH infusion began. In both experiments, FSH infusion was associated with an increase in circulatory concentrations of LH $(P<0.01)$ and FSH $(P<0.001)$, but there was no difference with body condition in mean circulating gonadotrophin concentrations, the numbers of ovarian follicles $\geqslant 2.5 \mathrm{~mm}$ diameter, the proportion of these follicles that were oestrogenic or the mean rate of oestradiol secretion in vitro. It is concluded that differences in body condition of ewes do not affect the responsiveness of the ovary to FSH, in the presence or absence of oestradiol, as measured by the number, size and steroidogenic capacity of ovarian follicles present following FSH infusion.
\end{abstract}

\section{Introduction}

Ewes in high body condition have a higher rate of reproductive performance than ewes in low body condition as a result of their greater ovulation rate (Gunn, 1983). The ovulation rates of ewes in different body conditions are closely related to the numbers of large ovarian follicles present; ewes in high body condition have more large, oestrogenic, ovarian follicles than ewes in low body condition (Rhind and McNeilly, 1986; McNeilly et al., 1987; Rhind et al., 1989).

FSH has an essential role in the development of follicles to $\geqslant 2.5 \mathrm{~mm}$ diameter (McNeilly et al., 1991), but differences in follicle populations and ovulation rate associated with differences in body condition are not consistently associated with differences in circulating FSH concentrations (Findlay and Cumming, 1976; Rhind and McNeilly, 1986; Rhind et al., 1989). It was therefore postulated that differences in the pattern of follicle development associated with differences in body condition may be attributable to differences in the response of small ovarian follicles ( $<2.5 \mathrm{~mm}$ diameter) to $\mathrm{FSH}$ stimulation.

The aim of the first experiment was to determine whether the small $(<2.5 \mathrm{~mm}$ diameter $)$ follicles of ewes in different

Received 9 April 1992. levels of body condition had a different pattern of growth and development when subject to a similar FSH stimulus.

Ovarian follicle development also depends on an appropriate LH profile (McNeilly et al., 1991), although the importance of LH pulses is equivocal (McNatty et al., 1981). It is also likely to be affected by systemic or paracrine influences of other hormones, including oestradiol (Hutz, 1989). To investigate the role of one hormone, in this case FSH, its effect must be separated from those of other hormones.

The possibility of confounding effects of differences in LH pulse frequency, which could be associated with differences in body condition, were eliminated by testing ovarian sensitivity to FSH using a simple experimental model. The model involved chronic treatment with a $\mathrm{GnRH}$ agonist to suppress circulating FSH concentrations and eliminate LH pulses (McNeilly and Fraser, 1987).

As this treatment inhibits the development of follicles $\geqslant 2.5 \mathrm{~mm}$ diameter, it is likely that circulating oestradiol concentrations were low in these animals. This deficiency could have affected the pattern of ovarian follicle development, as oestradiol is known to affect ovarian function (Hutz, 1989), although the nature of the effect seems to differ with species and experimental conditions. The aim of the second experiment was to determine whether the pattern of response of small follicles to FSH was modified by body condition in ewes in 
which circulating oestradiol concentrations were raised to concentrations broadly equivalent to those of normal cyclic animals. This hypothesis was tested using the same basic model as in Expt 1 but, in addition, Silastic implants containing oestradiol were inserted subcutaneously in all ewes.

\section{Materials and Methods}

\section{Experiment 1}

Animals and management. In early September, 40 mature Scottish Blackface ewes with a mean liveweight of $50.4 \mathrm{~kg}$ $(\mathrm{SEM}=1.04)$ and a mean body condition score (Russel et al., 1969) of 2.21 (SEM $=0.038$ ) were allocated, on the basis of liveweight and body condition, to two initially similar groups. Ewes of each group were then fed different amounts of dried grass pellets, hay, or both so that they achieved condition scores of $\geqslant 2.75$ (high; H) or $\leqslant 1.75$ (low; L) by early November. Thereafter, ewes were fed $1400 \mathrm{~g}$ dried grass pellets and $250 \mathrm{~g}$ grass hay per animal per day $(\mathrm{H})$ or $600 \mathrm{~g}$ pellets and $250 \mathrm{~g}$ hay per animal per day (L); these different feeds were designed to maintain differences in body condition throughout the experiment. All ewes were weighed and their condition was scored at ten-day intervals, and rations were adjusted, on an individual animal basis, so that they maintained differences in body condition.

Experimental procedures. In early November, osmotic minipumps (Alzet pump model $2 \mathrm{ML} 4$, Alza Corp., Palo Alto, CA) were inserted subcutaneously into the flank of each ewe (day 1 ); each pump contained $2 \mathrm{ml} \mathrm{GnRH}$ agonist (buserelin, Hoechst AG, Frankfurt; delivering $50 \mu \mathrm{g} \mathrm{day}^{-1}$ ). A second pump was inserted on day 22 (before the supply of buserelin in the first pump was exhausted) so that all ewes were subject to the influence of $\mathrm{GnRH}$ agonist until the end of the experiment. The first pump was not removed.

At day 22, the ovaries of ten ewes of each condition score group were examined by laparoscopy to assess their follicle populations and the efficacy of the GnRH agonist treatment.

From day 28 all ewes were infused via a jugular catheter for $72 \mathrm{~h}$, with ovine $\mathrm{FSH}(\mathrm{NIH}-\mathrm{oFSH}-17)$ at a rate of $7 \mu \mathrm{g}$ per ewe per hour (group H) or $5 \mu \mathrm{g}$ per ewe per hour (group L). Pilot studies had indicated that infusion rates had to differ according to the mean liveweight of the groups to achieve mean circulating FSH concentrations that were similar in ewes of both treatment groups and which were similar to those of normal, untreated ewes.

For three days before infusion and on each day of the infusion, blood samples were collected twice a day via jugular venepuncture and analysed for FSH concentration.

At the end of the infusion period, the right ovary was removed from each ewe by mid-line ventral laparotomy under general anaesthesia. All follicles $\geqslant 2.5 \mathrm{~mm}$ diameter were dissected from the ovary and their diameters recorded to the nearest $0.1 \mathrm{~mm}$ using a stereomicroscope fitted with an ocular graticule. The follicles were then incubated individually, under air, for $2 \mathrm{~h}$ in $1 \mathrm{ml}$ culture medium (Medium 199, Flow Laboratories, Irvine) at $37^{\circ} \mathrm{C}$. The medium was subsequently analysed for oestradiol and testosterone concentrations.
Immediately after hemi-ovariectomy, ewes were injected with 750 iu of hCG (Chorulon, Intervet Laboratories Ltd, Cambridge, $\mathrm{UK}$ ) to induce ovulation of follicles on the remaining ovary. Blood samples were subsequently collected daily and analysed for progesterone to provide a measure of luteal function. Supplementary injections of hCG were administered on days 3 and 7 after hCG injection and presumed ovulation to sustain luteal function. At days 6 and 12 after hCG injection and presumed ovulation the remaining ovaries were removed (ten animals from each group at each time) and numbers of corpora lutea present were recorded.

\section{Experiment 2}

Animals and management. Thirty mature Scottish Blackface ewes with an initial mean ( \pm SEM) liveweight of $55.2 \pm 1.10 \mathrm{~kg}$ and a mean condition score of $2.28 \pm 0.059$ were divided into pairs with similar body condition scores and within pairs were allocated randomly to two groups and fed differentially from late September so that they achieved high and low scores of body condition, similar to those of ewes in Expt 1 .

Experimental procedures. The experimental protocol used was similar in most respects to that of Expt 1 except that all ewes were killed 12 days after the first ovariectomy. In this experiment, at the time of insertion of the second minipump containing $\mathrm{GnRH}$ agonist (2I days after insertion of the first pump and 7 days before FSH infusion), a Silastic implant containing oestradiol was inserted subcutaneously in each ewe. The implants were of the type described by Karsch et al. (1973) and comprised Silastic tubing (Dow Corning Corp., Midland, MI) with internal and external diameters of 0.335 and $0.465 \mathrm{~cm}$, respectively. Each implant was $4 \mathrm{~cm}$ long of which $2 \mathrm{~cm}$ was packed with oestradiol (Sigma Chemicals, UK). The ends of the implants were sealed with elastomer (Dow Corning Corp., Midland, MI). Before use, all implants were incubated at $37^{\circ} \mathrm{C}$ in a solution of $1 \%$ BSA to confirm that they were sealed. They were designed to induce circulating oestradiol concentrations of approximately $4 \mathrm{pg} \mathrm{ml}^{-1}$, a concentration broadly similar to that of the peripheral circulation of a normal ewe during the luteal phase of the cycle. The implants were left in place until the end of the experiment.

Hormone assays. For each of the hormones measured, all samples were included in a single assay for each experiment. FSH and LH concentrations were determined using the techniques of McNeilly et al. (1976) and McNeilly et al. (1986), respectively. The assay sensitivities were $0.2 \mathrm{ng} \mathrm{m}^{-1}(\mathrm{NIH}-$ oFSH-RP-1) and $0.2 \mathrm{ng} \mathrm{ml}^{-1}$ (NIH-oLH-S23). The intra-assay coefficients of variation were 8.2 and $6.2 \%$ for the FSH and LH assays, respectively.

Plasma samples were analysed for progesterone using the method of Djahanbakhch et al. (1981). Testosterone and oestradiol contents of the culture media were determined using the methods of Webb et al. (1985). The assay sensitivities were $0.08 \mathrm{ng}$ progesterone $\mathrm{ml}^{-1}, 0.025 \mathrm{ng}$ testosterone $\mathrm{ml}^{-1}$ and $0.05 \mathrm{ng}$ oestradiol $\mathrm{ml}^{-1}$. Intra-assay coefficients of variation were $9.0,8.0$ and $8.4 \%$ for progesterone, testosterone and oestradiol, respectively. 
Table 1. Mean ( \pm SEM) liveweights $(\mathrm{kg})$ and condition scores of ewes fed to achieve high $(\mathrm{H})$ and low $(\mathrm{L})$ body condition immediately before FSH infusions and at the end of the experiments

\begin{tabular}{|c|c|c|c|c|}
\hline & \multicolumn{2}{|c|}{ Body condition } & \multicolumn{2}{|c|}{ Liveweight } \\
\hline & Pre-infusion & +2 weeks & Pre-infusion & +2 weeks \\
\hline \multicolumn{5}{|c|}{$\begin{array}{l}\text { Expt } 1 \\
\text { (No oestradiol implant) }\end{array}$} \\
\hline High & $2.94 \pm 0.032$ & $2.94 \pm 0.032$ & $65.3 \pm 1.38$ & $64.9 \pm 1.22$ \\
\hline Low & $1.76 \pm 0.023$ & $1.78 \pm 0.018$ & $46.4 \pm 1.76$ & $46.0 \pm 1.78$ \\
\hline \multicolumn{5}{|c|}{$\begin{array}{l}\text { Expt } 2 \\
\text { (Oestradiol implant) }\end{array}$} \\
\hline High & $2.93 \pm 0.047$ & $2.90 \pm 0.033$ & $57.1 \pm 1.47$ & $60.0 \pm 1.57$ \\
\hline Low & $1.83 \pm 0.048$ & $1.87 \pm 0.050$ & $44.7 \pm 1.14$ & $44.2 \pm 1.18$ \\
\hline
\end{tabular}

\section{Statistical analyses}

The gonadotrophin data were analysed using a hierarchical structure with animal at the highest level, period (pre-infusion, infusion) at the next level and time relative to the beginning of the period at the lowest level. Effects of body condition were estimated at the highest level between animals. Effects of period were measured at the intermediate level and effect of sampling time and its interactions were estimated at the lowest level. The data were analysed by analysis of variance.

The effects of the presence or absence of oestradiol implants (Expt 2 versus Expt 1) on the gonadotrophin profiles were determined by pooling data from the two experiments analysing with a similar structure to that used previously, separating between and within animal information.

The follicle populations of ewes in each treatment were compared on the basis of size $(2.5-2.9 \mathrm{~mm} ; 3.0-4.9 \mathrm{~mm}$ or $\geqslant 5.0 \mathrm{~mm}$ diameter) and rate of oestrogen secretion in vitro (oestrogenic: secreting $>500 \mathrm{pg}$ oestradiol per follicle per hour; nonoestrogenic:secreting $<500$ pg oestradiol per follicle per hour; Webb et al., 1989). Mean numbers of large follicles and corpora lutea per ewe in each treatment were compared using a Student's $t$ test and the proportions of follicles in different size classes were compared using a $\chi^{2}$ test.

\section{Results}

\section{Liveweight and condition scores}

At the beginning of the FSH infusion, animals of the $\mathrm{H}$ and $\mathrm{L}$ treatments in both experiments differed in mean liveweight by at least $13 \mathrm{~kg}$ and by approximately one condition score unit (Table 1). These differences were generally maintained throughout the remainder of the experiment.

\section{Gonadotrophin profiles}

In both experiments FSH infusion was associated with significantly higher circulating concentrations of FSH $(P<0.001)$ compared with pre-infusion concentrations (Fig. 1). Mean LH concentrations were also higher $(P<0.01)$ during the infusion. However, there was no significant difference with body condition in the mean concentrations of either hormone before or during infusion (Table 2).

Mean LH concentrations were similar in all treatments and experiments. Mean FSH concentrations were lower in Expt 2 (oestradiol implant) than in Expt 1 (no oestradiol implant) during both pre-infusion $(P<0.001)$ and infusion $(P<0.01)$ periods. There were no significant interactions between effects of body condition and oestradiol treatment on mean LH and FSH concentrations in Expt 2.

\section{Ovarian follicle populations and corpora lutea}

In both experiments, no large ( $\geqslant 2.5 \mathrm{~mm}$ diameter) follicles were present in the ovaries of animals laparoscopically examined before $\mathrm{FSH}$ infusion.

Ovaries were not recovered from one L ewe in Expt 1 because they were encased in adhesions. This animal was therefore excluded from subsequent analyses.

At the end of the $72 \mathrm{~h}$ infusion, no large follicles were present on the ovaries of six other animals in Expt $1(5 \mathrm{H}, 1 \mathrm{~L})$ and four animals in Expt $2(1 \mathrm{H}, 3 \mathrm{~L})$ and no corpora lutea were present on the remaining ovaries which were removed 6 or 12 days later. These animals were deemed to have failed to respond to the FSH infusion and were excluded from the subsequent analyses of follicle data.

There was no difference between $\mathrm{H}$ and $\mathrm{L}$ ewes in the mean ( \pm SEM) numbers of large follicles present in the single ovaries recovered at the end of the FSH infusion in Expt 1 (H: $5.40 \pm 0.98$; L: $4.94 \pm 0.66$ ) or Expt 2 (H: $6.50 \pm$ 1.24; L: $5.92 \pm 1.01$ ).

In Expt 1 there were no significant differences between $\mathrm{H}$ and $L$ ewes in the proportions of follicles in each size $X$ oestrogenicity class (Table 3). In Expt 2 a higher proportion of the follicles were in the larger size classes but there was no significant difference with body condition in the distribution of follicles throughout the classes.

In Expt $I$ within each class of oestrogenicity there was no effect of body condition on the capacity to synthesize steroid as 
(a)

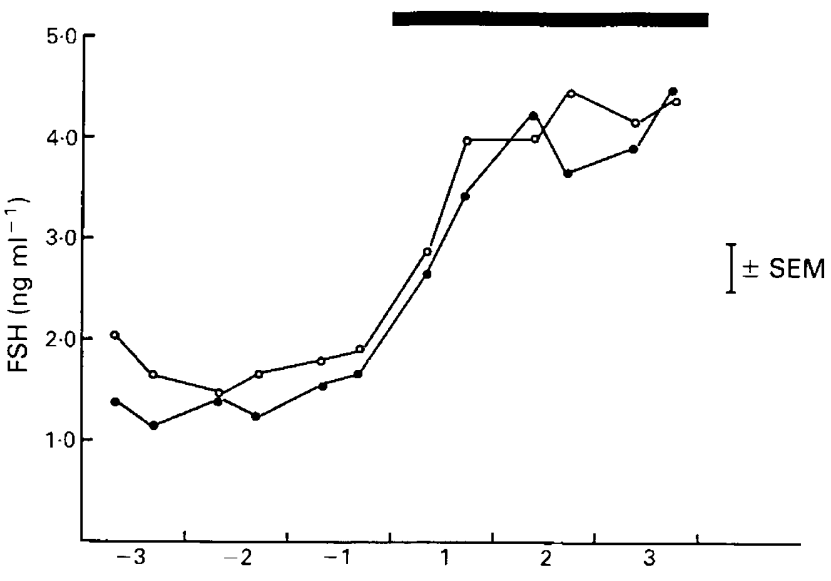

(b)

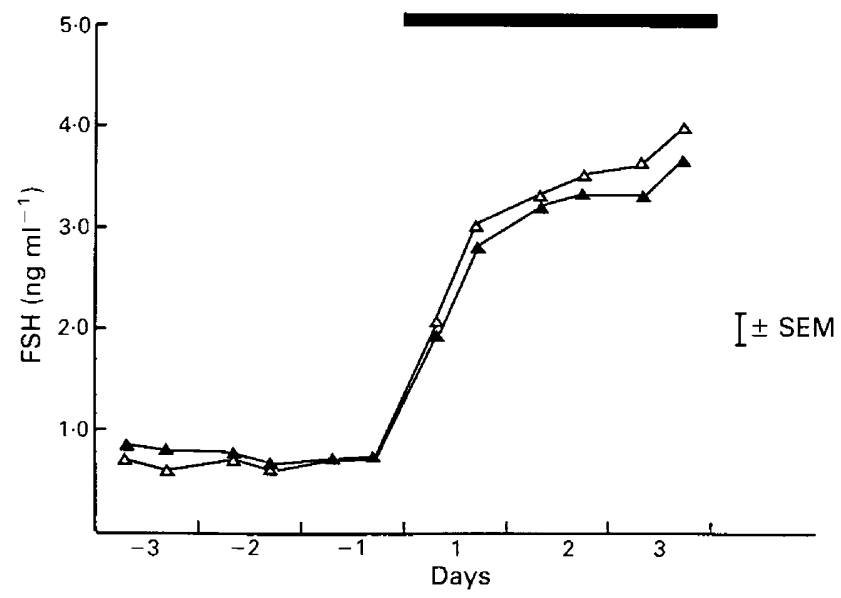

Fig. 1. Plasma FSH concentrations (mean \pm SEM) in ewes in high (O, $\Delta$ ) and low $(O, \triangle)$ body condition before and during infusion of $\mathrm{FSH}(\longrightarrow$ ) at $7 \mu \mathrm{g}$ per ewe per hour (ewes in high body condition) or $5 \mu \mathrm{g}$ per ewe per hour (ewes in low body condition) in (a) Expt I and (b) Expt 2. Four weeks before infusion ewes were implanted (s.c.) with minipumps designed to deliver $50 \mu \mathrm{g}$ gonadotrophin releasing hormone agonist (buserelin) day ${ }^{-1}$ (Expt 1 and 2). In Expt 2, at one week before FSH infusion ewes were also implanted (s.c.) with Silastic implants containing oestradiol, designed to induce circulating concentrations of oestradiol of approximately $4 \mathrm{pg} \mathrm{ml}^{-1}$.

indicated by mean rates of oestradiol and testosterone secretion by follicles in vitro (Table 4). However, in Expt 2, the oestrogenic follicles of $\mathrm{L}$ ewes produced significantly $(P<0.05)$ more oestradiol compared with those of $\mathrm{H}$ ewes.

Of the animals in Expt 1 that responded to FSH infusion, five of $15 \mathrm{H}$ ewes had corpora lutea on the second ovary (mean = 1.8 corpora lutea per ovary; range $=1-3$ ). A similar proportion of the $\mathrm{L}$ ewes ( 8 of 18 ) had corpora lutea (mean $=2.3$ corpora lutea per ovary; range $=1-5)$. In all but two of these ewes $(1 \mathrm{H}$, $1 \mathrm{~L})$, circulating progesterone concentrations $>1 \mathrm{ng} \mathrm{ml}^{-1}$ were recorded by day 6 of the cycle.

Only five of 30 ewes $(4 \mathrm{H}, \mathrm{IL})$ in the second experiment had corpora lutea at the second ovariectomy but abnormally large ( 9 to $20 \mathrm{~mm}$ diameter) follicles were present, many of which appeared to be partially luteinized, on the ovaries of these animals and on those of a further five animals $(3 \mathrm{H}, 2 \mathrm{~L})$. Circulating progesterone concentrations in all animals with corpora lutea were $>1 \mathrm{ng} \mathrm{ml}^{-1}$ at day 6 of the cycle following hCG injection but high progesterone concentrations were also recorded at times during the first 12 days after hCG in two other animals and these had large (>10 mm diameter) ovarian follicles which may have been partially luteinized.

\section{Discussion}

In the present studies, the absence of follicles $\geqslant 2.5 \mathrm{~mm}$ diameter before the FSH infusion, together with very low circulating FSH concentrations, in each of the experiments indicated that the GnRH agonist treatment inhibited FSH secretion, and therefore follicle growth beyond this size, as reported by McNeilly and Fraser (1987) and Picton et al. (1990a, b). Thus the follicle populations of the ewes in each condition score treatment were similar at the beginning of the infusion periods and the follicular response to $\mathrm{FSH}$ infusion could be assessed.

As different rates of $\mathrm{FSH}$ infusion were required to achieve similar mean circulating concentrations in $\mathrm{H}$ and $\mathrm{L}$ ewes, it is concluded that body condition affected pool size, entry or clearance rates. However, the results indicate that similar mean circulating FSH concentrations were achieved in ewes of the two treatments during the infusion periods in each of the two experiments.

Although the two experiments were conducted during different years, it seems likely that the significantly lower FSH concentrations of ewes in Expt 2 compared with Expt 1 were due to the greater amounts of oestradiol present in the implanted ewes. The circulating concentrations achieved nevertheless appear to be within the physiological range in both experiments since the numbers of follicles $\geqslant 2.5 \mathrm{~mm}$ diameter that were present at the end of the infusions were broadly similar to those reported for untreated ewes of the same breed (Rhind et al., 1989).

The results of Picton and McNeilly (1991) indicate that there is a large variation between individual animals in the threshold concentration of FSH required for development of large, oestrogenic follicles. This is likely to be the reason for the absence of large follicles in some ewes (those excluded from the analysis of follicle populations) following FSH infusion, while others with similar circulating FSH concentrations had many large oestrogenic follicles. However, the size distribution and patterns of oestrogenicity of the follicles that developed in response to FSH infusion in Expt 1 were similar in $\mathrm{H}$ and $\mathrm{L}$ ewes indicating that the ovarian follicles of ewes in the respective groups were not differentially sensitive to FSH per se. It is therefore concluded that the positive association between ewe body condition and the numbers of large oestrogenic follicles which was previously reported in ewes (Rhind and McNeilly, 1986; McNeilly et al., 1987) is not attributable to differences in ovarian sensitivity to $\mathrm{FSH}$.

In the experimental model used in Expt 1, the metabolic states of ewes in the two treatments are likely to be comparable to those of normal ewes in comparable nutritional states and consequently profiles of hormones such as insulin and growth hormone (which can influence follicle development and function 
Table 2. Mean plasma concentrations (ng $\mathrm{ml}^{-1}$ ) of $\mathrm{LH}$ and $\mathrm{FSH}$ before and during infusion of FSH in ewes in high (H) and low (L) body condition and without (Expt 1) and with (Expt 2) oestradiol implants

\begin{tabular}{|c|c|c|c|c|c|c|c|}
\hline & \multirow{2}{*}{\multicolumn{2}{|c|}{ Pre-fusion }} & \multirow{2}{*}{\multicolumn{2}{|c|}{ Infusion }} & \multirow[b]{3}{*}{ SED } & \multicolumn{2}{|c|}{ Significance ${ }^{a}$} \\
\hline & & & & & & & \\
\hline & $\mathrm{H}$ & $\mathrm{L}$ & $\mathrm{H}$ & L & & condition & Infusion \\
\hline \multicolumn{8}{|l|}{ Expt I } \\
\hline LH concentration & 0.58 & 0.58 & 0.72 & 0.73 & 0.094 & NS & $* * *$ \\
\hline FSH concentration & 1.39 & 1.74 & 3.67 & 3.93 & 0.339 & NS & $* * *$ \\
\hline \multicolumn{8}{|l|}{ Expt 2} \\
\hline LH concentration & 0.61 & 0.59 & 0.66 & 0.68 & 0.070 & NS & $* *$ \\
\hline FSH concentration & 0.76 & 0.70 & 3.04 & 3.24 & 0.191 & NS & $* * *$ \\
\hline
\end{tabular}

${ }^{2}$ There were no significant interactions between effects of body condition and FSH infusion.

Table 3. Numbers of oestrogenic (secreting $>500 \mathrm{pg}$ oestradiol per follicle per hour) and nonoestrogenic (secreting $<500 \mathrm{pg}$ oestradiol per follicle per hour) follicles in each follicle size class in ewes in high and low levels of body condition and without (Expt 1) and with (Expt 2) oestradiol

\begin{tabular}{|c|c|c|c|c|c|}
\hline & \multicolumn{4}{|c|}{ Body condition } & \multirow[b]{3}{*}{ All } \\
\hline & \multicolumn{2}{|c|}{ High } & \multicolumn{2}{|c|}{ Low } & \\
\hline & Oestrogenic & $\begin{array}{c}\text { Non- } \\
\text { oestrogenic }\end{array}$ & Oestrogenic & $\begin{array}{c}\text { Non- } \\
\text { oestrogenic }\end{array}$ & \\
\hline \multicolumn{6}{|c|}{ Follicle diameter (mm) } \\
\hline \multicolumn{6}{|c|}{ Expt I $(n=32)$} \\
\hline $2.5-2.9$ & 1 & 16 & 0 & 17 & 34 \\
\hline $3.0-4.9$ & 12 & 22 & 7 & 24 & 65 \\
\hline$>5.0$ & 20 & 2 & 28 & 2 & 52 \\
\hline Total & 33 & 40 & 35 & 43 & 151 \\
\hline \multicolumn{6}{|c|}{ Expt $2(n=26)$} \\
\hline $2.5-2.9$ & 1 & 4 & 0 & 5 & 10 \\
\hline $3.0-4.9$ & 19 & 16 & 13 & 11 & 59 \\
\hline$>5.0$ & 35 & 6 & 33 & 2 & 76 \\
\hline Total & 55 & 26 & 46 & 18 & 146 \\
\hline
\end{tabular}

The results pertain only to animals that showed an ovarian response to FSH infusion.

${ }^{*} \mathrm{Six}$ (Expt 1) and 17 (Expt 2) additional follicles $\geqslant 2.5 \mathrm{~mm}$ diameter were burst during dissection and were not incubated. In one (group $\mathrm{H}$ ) of the 33 ewes in which large follicles were recorded, the single large follicle was burst during dissection. The results are therefore based on the follicles of 32 ewes.

through effects on growth factor activity (Hammond et al., 1991)) are also likely to be normal. However, since there were no large follicles in the ovaries at the beginning of the infusion, patterns of follicular hormone production in GnRH treated animals would not be the same as in normal animals. Consequently intrafollicular and circulating concentrations of steroids, insulinlike growth factors and other hormones and interfollicular communication would have differed from that of untreated animals. The second experiment was designed to determine whether the presence of one of these hormones, oestradiol, affected the ovarian response to FSH in ewes in high and low body condition.

The oestradiol implants used in Expt 2 were designed to induce physiological oestradiol concentrations in the circu- lation. As this treatment did not reduce the ovarian response to FSH (as measured by follicle numbers, sizes and steroid production) in L ewes, it may be concluded that the reduction in follicle development associated with low levels of body condition in intact ewes cannot be attributed to a differential response to FSH in conjunction with oestradiol. It does not, however, rule out the possibility that there is a paracrine influence in the normal ewe, and the development of some large follicles is influenced by the production and secretion of large amounts of oestradiol by adjacent follicles; such influences would have been absent in the early stages of follicle development beyond $2.5 \mathrm{~mm}$ diameter in the present studies.

Indices of follicle development are of limited value if they are not related to the capacity of the follicles to ovulate. Although 
Table 4. Mean rates of secretion ( $\mathrm{pg} \mathrm{h}^{-1}$ ) of oestradiol and testosterone by oestrogenic (secreting $>500 \mathrm{pg}$ oestradiol per follicle per hour) and non-oestrogenic (secreting $<500 \mathrm{pg}$ per follicle per hour) follicles of ewes in high and low body condition and without (Expt 1) or with (Expt 2) oestradiol implants

\begin{tabular}{|c|c|c|c|c|c|c|c|}
\hline & \multicolumn{5}{|c|}{ Body condition } & & \\
\hline & \multicolumn{2}{|c|}{ High } & \multicolumn{2}{|c|}{ Low } & \multirow[b]{3}{*}{ SED } & \multirow{2}{*}{\multicolumn{2}{|c|}{ Significance of effect }} \\
\hline & & & & & & & \\
\hline & Oestrogenic & oestrogenic & Oestrogenic & oestrogenic & & Body condition & Class \\
\hline \multicolumn{8}{|l|}{ Expt 1} \\
\hline Oestradiol $^{\mathrm{a}}$ & 1209 & 172 & 1525 & 154 & 89.5 & NS & $* * *$ \\
\hline Testosterone & 1899 & 632 & 1848 & 554 & 125.0 & NS & $* * *$ \\
\hline \multicolumn{8}{|l|}{ Expt 2} \\
\hline Oestradiol $^{a}$ & 1392 & 248 & 2211 & 251 & 166 & $*$ & $* * *$ \\
\hline Testosterone $^{\mathrm{a}}$ & 1089 & 630 & 1338 & 315 & 126 & NS & $* * *$ \\
\hline
\end{tabular}

${ }^{2}$ Significant $(P<0.05)$ interaction between body condition and follicle class.

it was not possible in the study reported here to determine the physiological state of individual follicles that ovulated, the induction of corpus luteum formation by hCG indicates that at least some follicles were potentially ovulatory. Furthermore, since the circulating progesterone concentrations were high in most ewes with corpora lutea, it may be concluded that these corpora lutea were functional and so were presumably derived from functional preovulatory follicles. However, it appears that the presence of exogenous sources of oestrogen in conjunction with endogenous oestrogen may have disrupted the normal ovulatory processes in some animals so that abnormally large, sometimes luteinized, follicles developed but ovulation and corpus luteum formation did not occur.

It is concluded that differences with body condition in the pattern of ovarian follicle development in ewes are not attributable to differences in the sensitivity of the ovary to circulating FSH concentrations, either in the presence or absence of physiological concentrations of oestradiol in the circulation. The roles of $\mathrm{LH}$ pulses and of other hormones in the determination of patterns of follicle development, in conjuction with FSH and in the presence or absence of oestradiol, remain to be investigated.

The receipt of the highly purified hormone preparations for infusion and radioimmunoassay from the NIDDK and NHPP, Maryland, USA is gratefully acknowledged.

\section{References}

Djahanbahkch O, Swanston IA, Corrie JET and McNeilly AS (1981) Prediction of ovulation by progesterone Lancet ii 1164-1165

Findlay JK and Cumming IA (1976) FSH in the ewe: effect of season, liveweight and plane of nutrition in plasma FSH and ovulation rate Biology of Reproduction 15 335-342

Gunn RG (1983) The influence of nutrition on the reproductive performance of ewes. In Sheep Production - Proceedings of the 35th Easter School in Agricultural Science, University of Nottingham, pp 99-110. Ed. W Haresign. Butterworths, London

Hammond JM, Mondschein JS, Samaras SE, Smith SA and Hagen DR (1991) The ovarian insulin-like growth factor system Journal of Reproduction and Fertility Supplement 43 199-208

Hutz, RJ (1989) Disparate effects of estrogens on in vitro steroidogenesis by mammalian and avian granulosa cells Biology of Reproduction 40 709-713
Karsch FJ, Dierschke DJ, Weick RF, Yamaji T, Hotchkiss T and Knobil E (1973) Positive and negative feedback control by oestrogen of luteinizing hormone secretion in the rhesus monkey Endocrinology 92 799-804

McNatty KP, Gibb M, Dobson C and Thurley DC (1981) Evidence that changes in luteinizing hormone secretion regulate the growth of the preovulatory follicle in ewes joumal of Endocrinology 90 375-389

McNeilly AS and Fraser HM (1987) Effect of GnRH agonist-induced suppression of LH and FSH on follicle growth and corpus luteum function in the ewe Journal of Endocrinology 115 273-282

McNeilly AS, Jonassen JA and Fraser HM (1986) Suppression of follicular development after chronic LHRH immunoneutralization in the ewe Journal of Reproduction and Fertility 76 481-490

McNeilly AS, Jonassen JA and Rhind SM (1987) Reduced ovarian follicular development as a consequence of low body condition in ewes Acta Endocrinologica 115 75-83

McNeilly AS, Picton HM, Campbell BK and Baird DT (1991) Gonadotrophic control of follicle growth in the ewe Journal of Reproduction and Fertility Supplement 43 177-186

McNeilly JR, McNeilly AS, Walton JS and Cunningham FJ (1976) Development and application of a heterologous radioimmunoassay for ovine folliclestimulating hormone Journal of Endocrinology 70 69-79

Picton HM and McNeilly AS (1991) Evidence to support a follicle-stimulating hormone threshold theory for follicle selection in ewes chronically treated with gonadotrophin-releasing hormone agonist Journal of Reproduction and Fertility 93 43-51

Picton HM, Tsonis CG and McNeilly AS (1990a) FSH causes a time-dependent stimulation of follicle growth in the absence of pulsatile $\mathrm{LH}$ secretion in ewes chronically treated with gonadotrophin-releasing hormone agonist Journal of Endocrinology 126 297-307

Picton HM, Tsonis CG and McNeilly AS (1990b) The antagonistic effect of exogenous LH pulses on FSH-stimulated preovulatory follicle growth in ewes chronically treated with a gonadotrophin-releasing hormone agonist Joumal of Endocrinology 127 273-283

Rhind SM and McNeilly AS (1986) Follicle populations, ovulation rates and plasma profiles of LH, FSH and prolactin in Scottish Blackface ewes in high and low levels of body condition Animal Reproduction Science 10 105-115

Rhind SM, McMillen SR, McKelvey WAC, Rodriguez-Herrejon FF and McNeilly AS (1989) Effect of the body condition of ewes on the secretion of LH and FSH and the pituitary response to gonadotrophin-releasing hormone Journal of Endocrinology $120497-502$

Russel AJF, Doney JM and Gunn RG (1969) Subjective assessment of body fat in live sheep Journal of Agricultural Science 72 451-454

Webb R, Baxter G, McBride D, Norblom GD and Shaw MPK (1985) The measurement of testosterone and oestradiol- $17 \beta$ using iodinated tracers and incorporating an affinity chromatography extraction procedure Journal of Steroid Biochemistry 23 1043-1051

Webb R, Gauld IK and Driancourt MA (1989) Morphological and functional characterization of large antral follicles in three breeds of sheep with different ovulation rates Journal of Reproduction and Fertility $87243-255$ 